This PDF is a selection from a published volume from the National Bureau of Economic Research

Volume Title: Growth and Productivity in East Asia, NBER-East Asia Seminar on Economics, Volume 13

Volume Author/Editor: Takatoshi Ito and Andrew K. Rose, editors

Volume Publisher: University of Chicago Press

Volume ISBN: 0-226-38680-5

Volume URL: http://www.nber.org/books/ito_04-2

Conference Date: June 20-22, 2002

Publication Date: June 2004

Title: The Contribution of FDI Flows to Domestic Investment in Capacity, and Vice Versa

Author: Assaf Razin

URL: http://www.nber.org/chapters/c10747 


\section{The Contribution of FDI Flows \\ to Domestic Investment in \\ Capacity, and Vice Versa}

Assaf Razin

\subsection{Introduction}

The term "foreign direct investment" (FDI) usually brings to mind a significant contribution of FDI to domestic investment and to capital inflows. However, there has been a lot of skepticism concerning the contribution of FDI to these engines of growth. As noted by Froot (1991), FDI (the purchase by a domestic resident of a controlling stake in a foreign company) actually requires neither capital flows nor investment in capacity. Conceptually, FDI is an extension of corporate control over international boundaries. Froot put it succinctly: "When Japanese-owned Bridgestone takes control over the US firm Firestone, capital need not flow into the US. US domestic lenders can largely finance the equity purchase. Any borrowing by Bridgestone from foreign-based third parties also does not qualify as FDI (although it would count as an inflow of portfolio capital into the US). And, of course, in such acquisition there is no investment expenditure; merely an international transfer in the title of corporate assets." Does this example capture the essence of FDI in emerging economies?

The answer we provide in this paper, based on a new theory and new empirical evidence, is that FDI flows do play an important role in the skimming of high-productivity investment projects and thereby contribute significantly to domestic investment in both the quantity and the quality dimensions.

Assaf Razin is Mario Henrique Simonsen Professor of Public Economics at Tel Aviv University, Friedman Professor of International Economics at Cornell University, and a research associate of the National Bureau of Economic Research. 


\subsection{Old and New Theories}

Theories of FDI can essentially be divided into two categories: micro (industrial organization) theories and macro finance (cost of capital) theories. The early literature that explains FDI in microeconomic terms focuses on market imperfections and on the desire of multinational enterprises to expand their market power (see Caves 1971). Subsequent literature centered more on firm-specific advantages, owing to product superiority or cost advantages that stemmed from economies of scale, multiplant economies and advanced technology, or superior marketing and distribution (see Helpman 1984). According to this view, multinationals find it cheaper to expand directly in a foreign country, rather than through trade, in cases where the advantages associated with cost or product are based on internal, indivisible assets based on knowledge and technology. Alternative explanations for FDI have focused on regulatory restrictions, including tariffs and quotas, that either encourage or discourage cross-border acquisitions, depending on whether one considers horizontal or vertical integrations.

Studies examining the macroeconomic effects of exchange rate on FDI focused on the positive effects of an exchange rate depreciation of the host country on FDI inflows, because it lowers the cost of production and investment in the host countries, raising the profitability of FDI. The wealth effect is another channel through which a depreciation of the real exchange rate could raise FDI. A depreciation of the real exchange rate, by raising the relative wealth of foreign firms, could make it easier for those firms to use retained profits to finance investment abroad and to post a collateral in borrowing from domestic lenders in the host country capital market (see Froot 1991 and Razin and Sadka 2003). There is also a large literature on different forms of spillovers from inward investors in the form of new technologies, new ideas, and capital accumulation on the growth of output in the domestic economy (see Blomström, Kokko, and Globerman 2001).

What is the essential difference between portfolio investment and FDI investment from the point of view of corporate governance?

Management under portfolio equity ownership may be plagued by a free-rider problem. Under dispersed ownership, if an individual shareholder does something to improve the quality of management, the benefits will also accrue to all other shareholders (see Hart 2000). In contrast, the FDI investor, who is endowed with management skills and gains control of the firm, has better incentives to pursue proper monitoring of management and will be in a better position to micromanage the firm. Furthermore, based on possessing "intangible capital" in his or her source country, the FDI investor can apply more efficient management standards in the host country compared to domestic investors. Thus, the unique advantage to 
FDI, which has only recently been explored, is the potential for superior micromanagement, based on the specialization in niches of industry. Important issues with FDI from this standpoint are (1) what the salient characteristics are of the free-FDI-flows equilibrium, when FDI investors take control over domestic firms; (2) what constitutes the gains from FDI flows to the host economy, given that the foreign investors appropriate the private rewards resulting from their superior management skills; and (3) whether or not the free-FDI-flows regime is more efficient than freeportfolio-flows regime.

In an integrated capital market, with full information, all forms of capital flows (FDI, loans, and portfolio equity and debt) are indistinguishable. In the presence of incomplete information, these flows are significantly different from one another. In Razin and Sadka (2002), we developed a stylized model of FDI in the presence of imperfect information with respect to the firm's productivity.

We formalized the unique advantage of FDI investment over other types of investment in a stylized model. Suppose that initially all firms are still owned by original (domestic) uninformed owners, and suppose that the productivity shock is purely idiosyncratic. At the beginning of the first period, when investment decisions are made, firms are still uninformed about the productivity shock (the productivity level of the specific firm that they own). It will be revealed only in the second period, when output from new capital becomes public knowledge. In order to make new investment the firm must first incur a fixed setup cost. As the firms are all ex ante identi$\mathrm{cal}$, if they have to make the investment decision based on this level of information, they will all invest the same, in accordance with the expected level of the productivity factor. Assume now that at this stage, before the productivity factor is known, foreign direct investors step in. Upon acquiring and effectively managing the firm, the FDI investor can better monitor the productivity of the firm than his or her domestic investor counterpart. He or she can thus fine-tune the level of capital stock more closely to the value of the productivity factor. Anticipating this fine-tuned investment schedule, the value of the firm to the potential FDI investor is larger than the reservation value to the original owner and the corresponding bid value to potential domestic investors. Therefore, FDI investors will outbid domestic investors for the firms in the domestic industry. Competition among potential FDI investors will drive the price up close to the price that reflects the upgraded management of the firm. The initial domestic owners will gain the rent, which is equal to difference between the FDI investor's shadow price and the initial owner's reservation price.

If the competition between potential FDI investors is perfect, all the benefits from the superior FDI management skills accrue to the host economy, leaving the FDI investors with a return on their investment just equalling 
the world rate of interest. The gains to the host economy from FDI inflows can in this case be classified into two categories. First, there are the conventional gains that stem from opening the economy to the new flow of capital, thereby allowing a more efficient intertemporal allocation of consumption (e.g., via consumption smoothing). Second, there are the intrinsic gains associated with the superior micromanagement by FDI investors. The entire gain of the FDI investors is captured by the domestic economy because of assumed perfect competition among these investors over the domestic firms. If, however, there is imperfect competition among FDI investors, the gains will split between them and the host country.

The economic gains from FDI, relative to portfolio inflows, lie only in the efficiency of investment, since in both cases there are consumptionsmoothing effects and the same world interest rate $(r)$ prevails in the host country in both the FDI-flows regime and the portfolio-flows regime. In other words, the gains from FDI, in comparison to portfolio flows, do not include the traditional gains from opening up the domestic capital market to foreign capital inflows because these traditional gains are also present in the portfolio-flows regime. Razin and Sadka (2002) were able also to show that, under some plausible conditions on the form of the production function, the size of the aggregate stock of capital is larger under FDI than under portfolio equity flows.

\subsection{The Evidence ${ }^{1}$}

Like its theoretical counterpart, empirical work has tended to focus either on underlying factors to explain the location of FDI flows across countries or on explaining the cyclical behaviour of FDI flows using macroeconomic variables and assessing the contribution of FDI flows to investment and growth.

To what extent is there empirical support for such claims of the significant impact of FDI on domestic investment?

\subsubsection{Previous Literature}

A comprehensive study by Bosworth and Collins (1999) provides evidence concerning the effect of capital inflows on domestic investment for fifty-eight developing countries during 1978-95. The authors distinguish among three types of inflows: FDI, portfolio investment, and other financial flows (primarily bank loans). Bosworth and Collins find that an increase of a dollar in capital inflows is associated with an increase in domestic investment of about fifty cents. (Both capital inflows and domestic

1. See Borensztein, DeGregorio, and Lee (1998) and Bosworth and Collins (1999) for a similar panel data analysis. 
investment are expressed as percentages of gross domestic product [GDP]). This result, however, masks significant differences among different types of inflows. Foreign direct investment appears to bring about close to a one-for-one increase in domestic investment; there is virtually no discernible relationship between portfolio inflows and investment (little or no impact), and the impact of loans falls between those of the other two. These results hold both for the fifty-eight-country sample and for a subset of eighteen emerging markets (see fig. 5.1).

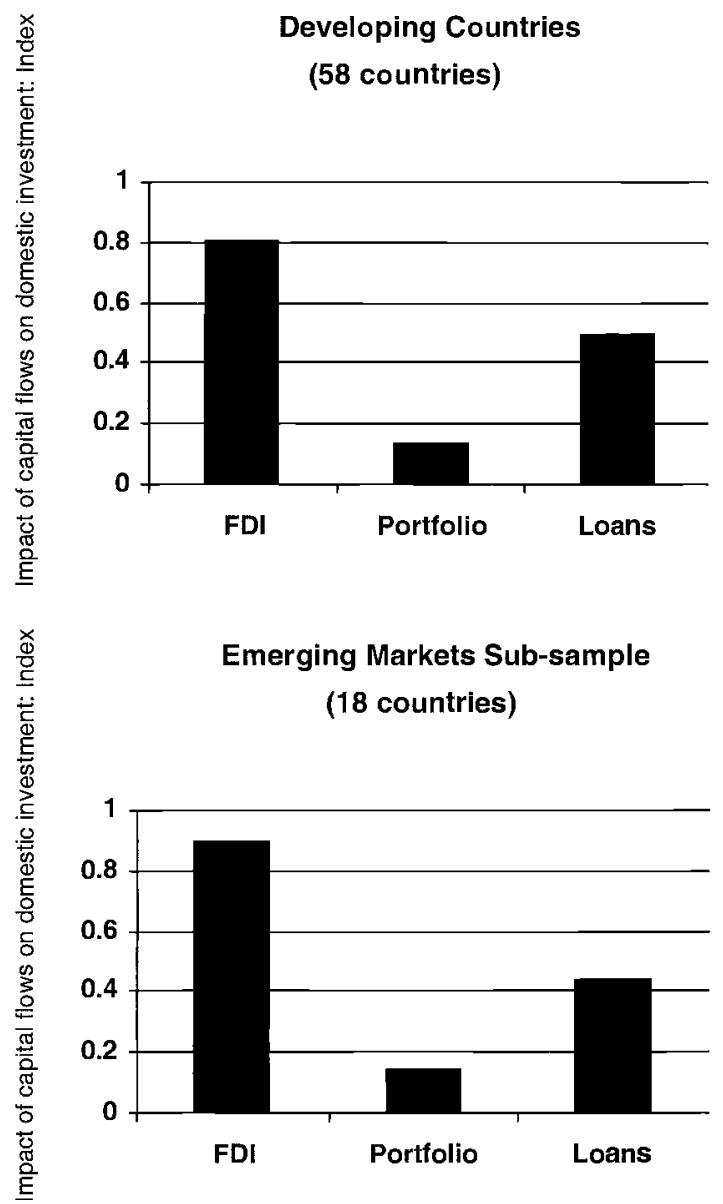

Fig. 5.1 Estimated impact of capital flows on domestic investment

Source: Loungani and Razin (2001), based on Bosworth and Collins (1999).

Note: The height of the bar represents the estimated impact of $\$ 1$ of the indicated capital flow on domestic investment. 


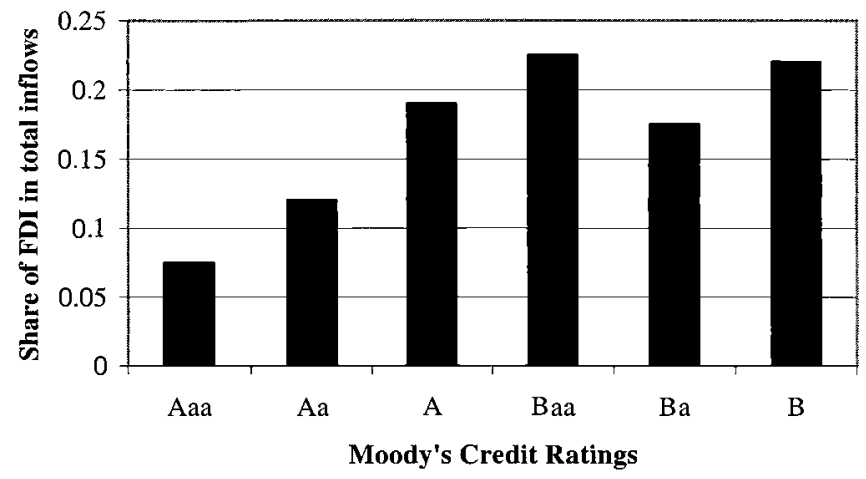

Fig. 5.2 FDI's share in total inflows is higher in countries with weaker credit ratings Source: Albuquerque (2003).

An additional (striking) feature of FDI flows that was noted in previous literature is that the share of FDI in total inflows is higher in riskier countries, as measured either by countries' credit ratings for sovereign (government) debt or other indicators of country risk (see fig. 5.2). There is also some evidence that the FDI share is higher in countries where the quality of corporate governance institutions is lower. What can explain these seemingly paradoxical findings? One explanation is that FDI is more likely, compared with other forms of capital flows, to take place in countries with missing or inefficient markets. In such settings, foreign investors will prefer to operate directly instead of relying on local financial markets, suppliers, or legal arrangements.

\subsubsection{Determinants of Foreign Direct Investment Flows: A Gravity Model}

Razin, Rubinstein, and Sadka (2003) employ a gravity model of bilateral FDI and portfolio capital flows in order to explain determinants of the mobility of financial capital across countries. The authors estimate jointly a participation equation (the decision whether to export FDI at all) and a gravity equation (the decision how much FDI exports to make). They find that the error terms in these two equations are negatively and significantly correlated. The negative correlation suggests that the source countries with relatively low set up costs of FDI investment are also those with high marginal productivity of capital. These findings are summarized in table 5.1.

In Mody, Razin, and Sadka (2002) we interpret the industry specialization measure in the source country as an indication of a comparative advantage to the potential foreign direct investors in eliciting good invest- 
Determinants of FDI in a Gravity Equation and Selection Equation

\begin{tabular}{lcc}
\hline & Gravity & Selection \\
\hline Host GDP per capita & 0.762 & 0.264 \\
& $(0.054)$ & $(0.030)$ \\
Source GDP per capita & 0.002 & 1.928 \\
& $(0.207)$ & $(0.073)$ \\
Common language & 1.209 & 0.024 \\
& $(0.085)$ & $(0.049)$ \\
Average years of schooling (host) & 0.087 & 0.000 \\
Average years of schooling (source) & $(0.023)$ & $(0.014)$ \\
& 0.295 & 0.058 \\
rho & $(0.025)$ & $(0.015)$ \\
No. of observations & -0.585 & -0.585 \\
& $(0.077)$ & $(0.077)$ \\
\hline
\end{tabular}

Source: Razin, Rubinstein, and Sadka (2003).

Notes: Maximum livelihood estimation: FDI (real US\$) from source to destination country (1981-98, three-year averages). Numbers in parentheses are standard errors.

ment opportunities in the destination country, relative to domestic investors in the host country. This advantage may stem, for example, from the ability of FDI investors to apply better industry-specific micromanagement standards. To capture this element we assume a lower cost of cream skimming (of high-productivity firms) on the part of foreign direct investors. The second category of variables underscores the role of information as a determinant of FDI inflows. As banks are the main providers of debt capital in emerging markets, and they usually conduct rigorous scrutiny of the creditworthiness of their debtors, we conjecture that, ceteris paribus, firms with high debt-equity ratio tend to be more transparent. In this case, the advantage of FDI investors in their cream-skimming skills (that is, the selection of high-productivity firms) is less pronounced and therefore FDI inflows are less abundant.

\subsection{Capital Inflows, Investment in Capacity, and Growth: Panel Data}

\subsubsection{Empirical Framework for the Panel-Data Analysis}

In this subsection I describe the econometric approach for the estimation of the interactions between domestic investment, FDI flows, international loans, and international portfolio investment. The sample consists of sixty-four developing countries, including Israel, ${ }^{2}$ in the period 1976 to

2. This section draws on Hecht, Razin, and Shinar (2003). 
1997 (twenty-two years in total; see appendix A). All the variables but the dummies are expressed in terms of GDP percentages. The source of data is the World Development Indicators (WDI) database (see appendix A). The system of equations is given by

$$
\text { 1. } \begin{aligned}
I= & \beta_{i 1 j}+\beta_{i 2} I(-1)+\beta_{i 3} \mathrm{DY}+\beta_{i 4} \mathrm{DY}(-1)+\beta_{i 5} \mathrm{FDI}+\beta_{i 6} P+\beta_{i 7} L \\
& +\beta_{i 8} G
\end{aligned}
$$

2. FDI $=\beta_{f 1 j}+\beta_{f 2} \mathrm{FDI}(-1)+\beta_{f 3} I+\beta_{f 4} \mathrm{DY}+\beta_{f 5} \mathrm{DY}(-1)+\beta_{f 6}$ Res 2

3. $L=\beta_{l l j}+\beta_{l 2} L(-1)+\beta_{l 3} I+\beta_{l 4} \mathrm{DY}+\beta_{l 5} \mathrm{DY}(-1)$

4. $\quad P=\beta_{p 1 j}+\beta_{p 2} P(-1)+\beta_{p 3} I+\beta_{p 4} \mathrm{DY}+\beta_{p 5} \mathrm{DY}(-1)+\beta_{p 6} \operatorname{Res} 1$,

where

$I=$ gross domestic investment ( $\%$ of GDP)

FDI $=$ foreign direct investment $(\%$ of GDP)

$L=$ bank loans ( $\%$ of GDP)

$P=$ portfolio investment flows ( $\%$ of GDP)

$\mathrm{DY}=$ annual percentage growth rate of GDP

$G=$ general government consumption ( $\%$ of GDP)

Res $1=$ multiple exchange rates $($ single exchange rate $=0 ;$ more than one $=1$ )

Res $2=$ restrictions on current account transactions (no controls $=0$; controls $=1$ )

$j=$ country index $, j=01,02,03, \ldots, 64$

The four-equation system has four endogenous variables: $I$, FDI, $P$, and $L$ as dependent variables and observations. Every equation also includes, as an explanatory variable, the dependent variable lagged one period. The exogenous variables used for identification are government expenditure $(G)$, a dummy variable for multiple exchange rates (Res1), a dummy variable for restrictions on current account transactions (Res2), and lagged dependent variables.

Table 5.2 describes the interactions among the endogenous and the exogenous variables in the four-equation system.

Two versions are estimated: ordinary least squares (OLS) regressions, as a benchmark, and two-stage least squares (TSLS) regressions with a country-specific effect. To avoid nonstationarity of the residuals in the fourequation system, we introduce lagged dependent variables on the righthand side of the equation system.

\subsubsection{Domestic Investment: Findings}

Tables 5.3 through 5.6 present the estimation results, and we discuss them equation by equation. 


\begin{tabular}{|c|c|c|c|c|c|c|c|c|c|c|c|c|c|}
\hline & \multicolumn{4}{|c|}{$\begin{array}{c}\text { Endogenous } \\
\text { Variables }\end{array}$} & \multicolumn{9}{|c|}{ Exogenous Variables } \\
\hline & FDI & $P$ & $L$ & $I$ & $I(-1)$ & FDI $(-1)$ & $P(-1)$ & $L(-1)$ & DY & $\mathrm{DY}(-1)$ & $G$ & Res2 & Res 1 \\
\hline$I$ & + & + & + & + & & & & + & + & + & & & \\
\hline FDI & & & & + & & + & & & + & + & & & + \\
\hline$P$ & & & & + & & & + & & + & + & & & + \\
\hline$L$ & & & & + & & & & + & + & + & & & \\
\hline
\end{tabular}

Table 5.3 Determinants of Domestic Investment in Capacity

\begin{tabular}{lcc}
\hline & OLS & TSLS \\
\hline Foreign direct investment, FDI & 0.16 & 0.23 \\
& $(5.2)$ & $(6.8)$ \\
Loan inflows, $L$ & -0.06 & 0.12 \\
& $(-2.2)$ & $(3.0)$ \\
Portfolio inflows, $P$ & 0.03 & 0.18 \\
& $(0.3)$ & $(2.0)$ \\
Lagged domestic investment, $I(-1)$ & 0.87 & 0.66 \\
& $(96.1)$ & $(51.2)$ \\
Output growth, DY & 0.15 & 0.15 \\
& $(10.4)$ & $(10.9)$ \\
Lagged output growth, DY(-1) & 0.06 & 0.06 \\
& $(3.8)$ & $(4.4)$ \\
Government expenditure, $G$ & 0.03 & 0.01 \\
& $(2.3)$ & $(0.5)$ \\
Long-run effect of FDI on $I$ & 0.94 & 0.68 \\
Long-run effect of $L$ on $I$ & -0.35 & 0.35 \\
Long-run effect of $P$ on $I$ & 0.18 & 0.53 \\
$R^{2}$ adjusted & 0.40 & 0.53 \\
\hline
\end{tabular}

Notes: Estimated using Eviews software. $I(-1)$, FDI, $P, L$, and $G$ are in terms of ratio to GDP; $t$-values appear in parentheses.

We start with table 5.3, which describes the effects of capital inflows on domestic investment.

The coefficient of FDI is significant in the OLS and TSLS regressions. Long-run FDI effect on domestic investment is 0.94 in the OLS regression and 0.68 in the TSLS regression. Thus, potential for an upward bias in the OLS estimation procedure appears to be validated. Indeed the effect of FDI on domestic investment is smaller in TSLS regressions. The loan coefficient is significant and positive in both the OLS and the TSLS regressions, at a similar magnitude. However, the long-run coefficient (adjusted 
Table 5.4

Determinants of FDI Inflows

\begin{tabular}{lcc}
\hline & OLS & TSLS \\
\hline Domestic investment, $I$ & 0.03 & 0.07 \\
& $(3.0)$ & $(5.0)$ \\
Lagged foreign direct investment, FDI $(-1)$ & 0.60 & 0.50 \\
& $(19.6)$ & $(16.0)$ \\
Output growth, DY & 0.01 & 0.02 \\
& $(0.10)$ & $(1.6)$ \\
Lagged output growth, DY(-1) & -0.01 & 0.02 \\
Dummy for capital controls, Res2 & $(-0.1)$ & $(1.3)$ \\
(no controls = 0; controls $=1)$ & -0.03 & -0.02 \\
Long-run effect of $I$ on FDI & $(-2.1)$ & $(-1.2)$ \\
$R^{2}$ adjusted & 0.08 & 0.14 \\
\hline
\end{tabular}

Notes: FDI and $I$ are in terms of ratio to GDP; $t$-values appear in parentheses.

for the lag structure of the regression) moves up from -0.35 in the TSLS regression. The coefficient of the portfolio-investment variable is not significant in the OLS regression and becomes significant in the TSLS regression. Interestingly, the long-run effect of FDI on domestic investment, 0.68 , exceeds the corresponding effect of portfolio investment, 0.53 , which in turn exceeds the effect of loans, 0.35 .

\section{Foreign Direct Investment Inflows}

Table 5.4 describes the effect of domestic investment on FDI inflows, allowing for the effects of a group of other traditional variables, such as growth and capital controls.

The coefficient of domestic investment is positive and significant in both the OLS and the TSLS regression. The long-run effect in the OLS $(0.08)$ is smaller than in the TSLS $(0.14)$.

\section{Loan Inflows}

Table 5.5 describes the effect of domestic investment on loan inflows, allowing for the effect of growth. The coefficient of domestic investment is negative and nonsignificant in the OLS but positive and significant in the TSLS regression. The long-run effect moves up from -0.03 in the OLS regression to 0.08 in the TSLS regression.

\section{Portfolio Inflows}

Table 5.6 describes the effect of domestic investment on portfolio investment inflows. The explanatory power of the regression is poor, however, and most of the right-hand-side variables have nonsignificant coefficients. 
Table 5.5 Determinants of Loans Inflows

\begin{tabular}{lcc}
\hline & OLS & TSLS \\
\hline Domestic investment, $I$ & -0.01 & 0.04 \\
& $(1.4)$ & $(3.0)$ \\
Lagged $L, L(-1)$ & 0.66 & 0.50 \\
& $(22.9)$ & $(16.7)$ \\
Output growth, DY & 0.01 & -0.001 \\
& $(0.8)$ & $(-0.05)$ \\
Lagged output growth, DY $(-1)$ & 0.02 & -0.0002 \\
& $(1.2)$ & $(-0.02)$ \\
Long-run effect of $I$ on $L$ & -0.03 & 0.08 \\
$R^{2}$ adjusted & 0.24 & 0.25 \\
\hline
\end{tabular}

Notes: $L(-1)$ and $I$ are in terms of ratio to GDP; $t$-values appear in parentheses.

Table 5.6

Determinants of Portfolio Investment Inflows

\begin{tabular}{lcc}
\hline & OLS & TSLS \\
\hline Domestic investment, $I$ & 0.004 & 0.01 \\
& $(0.5)$ & $(0.7)$ \\
Lagged portfolio investment, $P(-1)$ & 0.46 & 0.40 \\
& $(4.8)$ & $(4.8)$ \\
Output growth, DY & 0.001 & -0.001 \\
& $(0.2)$ & $(-0.1)$ \\
Lagged output growth, DY(-1) & 0.007 & 0.004 \\
& $(0.5)$ & $(0.3)$ \\
Dummy for multiple exchange rates, Res1 & -0.001 & -0.002 \\
(one exchange rate = 0; more than one $=1)$ & $(-0.6)$ & $(-0.9)$ \\
Long-run effect of $I$ on portfolio investment flows & 0.007 & 0.017 \\
$R^{2}$ adjusted & 0.03 & 0.13 \\
\hline
\end{tabular}

Notes: $P(-1)$ and $I$ are in terms of ratio to GDP; $t$-values appear in parentheses.

The regression analysis effectively flashes out an autocorrelation process of the portfolio investment flows.

\subsubsection{The Contribution of Capital Inflows to Output Growth: Findings}

In this section we estimate the contribution of FDI, loans, and portfolio investment to output growths. Similarly to the empirical framework in the first subsection of section 5.3.3, the system of equations is given by

1. $\mathrm{DY}=\beta_{i 1 j}+\beta_{i 2} \mathrm{DY}(-1)+\beta_{i 3} I+\beta_{i 4} I(-1)+\beta_{i 5} \mathrm{FDI}+\beta_{i 6} P+\beta_{i 7} L+\beta_{i 8} G$

$$
+\beta_{i 9} \log (\mathrm{GDP})
$$

2. FDI $=\beta_{f 1 j}+\beta_{f 2} \mathrm{FDI}(-1)+\beta_{f 3} \mathrm{DY}+\beta_{f 4} I+\beta_{f 5} I(-1)+\beta_{f 6}$ Res 2

$$
+\beta_{f 7} \log (\mathrm{GDP})
$$

3. $L=\beta_{l 1 j}+\beta_{l 2} L(-1)+\beta_{l 3} \mathrm{DY}+\beta_{l 4} I+\beta_{l 5} I(-1)+\beta_{l 6} \log (\mathrm{GDP})$ 


\begin{tabular}{|c|c|c|c|c|c|c|c|c|c|c|c|c|c|c|}
\hline & \multicolumn{4}{|c|}{$\begin{array}{l}\text { Endogenous } \\
\text { Variables }\end{array}$} & \multicolumn{10}{|c|}{ Exogenous Variables } \\
\hline & FDI & $P$ & $L$ & DY & $\mathrm{DY}(-1)$ & FDI $(-1)$ & $P(-1)$ & $L(-1)$ & $\log (G D P)$ & $I$ & $I(-1)$ & $G$ & Res2 & Res1 \\
\hline$I$ & + & + & + & & + & & & & + & + & + & + & & \\
\hline FDI & & & & + & & + & & & + & + & + & & + & \\
\hline$P$ & & & & + & & & + & & + & + & + & & & + \\
\hline$L$ & & & & + & & & & + & + & + & + & & & \\
\hline
\end{tabular}

4. $\quad P=\beta_{p 1 j}+\beta_{p 2} P(-1)+\beta_{p 3} \mathrm{DY}+\beta_{p 4} I+\beta_{p 5} I(-1)+\beta_{p 6}$ Res 1

$$
+\beta_{p 7} \log (\mathrm{GDP}) \text {, }
$$

where

$G=$ general government consumption ( $\%$ of GDP)

FDI $=$ foreign direct investment ( $\%$ of GDP)

$L=$ bank loans ( $\%$ of GDP)

$P=$ portfolio investment flows ( $\%$ of GDP)

$I=$ gross domestic investment ( $\%$ of GDP)

DY $=$ annual percentage growth rate of GDP

Res $1=$ multiple exchange rates $($ single exchange rate $=0 ;$ more than one $=1$ )

Res $2=$ restrictions on current account transactions (no controls $=0$; controls $=1$ )

$\log (\mathrm{GDP})=$ natural logarithm of GDP

$j=$ country index $, j=01,02,03, \ldots, 64$

Table 5.7 describes the interactions among the endogenous and the exogenous variable in the four-equation system.

\section{Output Growth}

Table 5.8 describes the effects of capital inflows on growth. The coefficient of FDI is significant in the OLS and TSLS regressions. Long-run FDI effect on output growth is 0.1 in the OLS regression and 0.23 in the TSLS regression. The effect of FDI on output growth is smaller in TSLS regressions. Thus, potential for a downward bias in the OLS estimation procedure appears to be demonstrated. The long-run coefficient in the TSLS regression is 0.23 .

The loan coefficient and the portfolio coefficient are not significant in the OLS and the TSLS regressions. However, the long-run coefficient of portfolio flows exceeds 0.1 .

\section{Foreign Direct Investment Inflows}

Table 5.9 describes the effect of output growth on FDI inflows, allowing for the effects of a group of other control variables, such as domestic investment and capital controls. 


\begin{tabular}{lcc}
\hline & OLS & TSLS \\
\hline Foreign direct investment, FDI & 0.09 & 0.20 \\
Loan inflows, $L$ & $(3.0)$ & $(5.0)$ \\
& 0.01 & 0.02 \\
Portfolio inflows, $P$ & $(0.2)$ & $(0.4)$ \\
& 0.05 & 0.10 \\
Lagged output growth, DY(-1) & $(0.6)$ & $(1.0)$ \\
& 0.12 & 0.12 \\
Domestic investment, $I$ & $(7.6)$ & $(6.9)$ \\
& 0.27 & 0.24 \\
Lagged domestic investment, $I(-1)$ & $(14.4)$ & $(11.4)$ \\
& -0.22 & -0.18 \\
Government expenditure, $G$ & $(-12.1)$ & $(-9.1)$ \\
& -0.19 & -0.19 \\
Log(GDP) & $(-8.4)$ & $(-7.9)$ \\
& -0.01 & -0.004 \\
Long-run effect of FDI on DY & $(-3.3)$ & $(-1.45)$ \\
Long-run effect of $L$ on DY & 0.1 & 0.23 \\
Long-run effect of $P$ on DY & 0.01 & 0.02 \\
$R^{2}$ adjusted & 0.06 & 0.11 \\
\end{tabular}

Notes: $I(-1)$, FDI, $P, L$, and $G$ are in terms of ratio to GDP; $t$-values appear in parentheses.

Table 5.9

Determinants of FDI Inflows

\begin{tabular}{lcc}
\hline & OLS & TSLS \\
\hline Output growth, DY & 0.02 & 0.05 \\
& $(1.3)$ & $(2.2)$ \\
Lagged foreign direct investment, FDI(-1) & 0.45 & 0.49 \\
& $(13.4)$ & $(13.4)$ \\
Domestic investment, $I$ & 0.07 & 0.08 \\
& $(3.8)$ & $(3.7)$ \\
Lagged domestic investment, I(-1) & -0.01 & -0.01 \\
& $(-0.5)$ & $(-0.4)$ \\
Dummy for capital controls, Res2 & -0.002 & -0.002 \\
(no controls = 0; controls =1) & $(-0.1)$ & $(-0.8)$ \\
Log(GDP) & 0.01 & 0.01 \\
& $(3.5)$ & $(3.0)$ \\
Long-run effect of DY on FDI & 0.04 & 0.05 \\
$R^{2}$ adjusted & 0.26 & 0.3 \\
\hline
\end{tabular}

Notes: FDI and $I$ are in terms of ratio to GDP; $t$-values appear in parentheses. 
The coefficient of output growth is positive and significant in the TSLS regression. The long-run effect is 0.05 .

\section{Loan Inflows}

Table 5.10 describes the effect of output growth on loans inflows, allowing for the effect of domestic investment. The coefficient of output growth is nonsignificant in both the regressions.

\section{Portfolio Inflows}

Table 5.11 describes the effect of output growth on portfolio investment inflows. The explanatory power of the regression is poor, however, and most of the right-hand-side variables have nonsignificant coefficients. The

Table 5.10

Determinants of Loans Inflows

\begin{tabular}{lcc}
\hline & OLS & TSLS \\
\hline Output growth, DY & -0.005 & -0.005 \\
Lagged $L, L(-1)$ & $(-0.3)$ & $(-0.2)$ \\
& 0.49 & 0.49 \\
Domestic investment, $I$ & $(14.2)$ & $(14.0)$ \\
& 0.06 & 0.07 \\
Lagged domestic investment, $I(-1)$ & $(3.2)$ & $(3.4)$ \\
Log(GDP) & -0.03 & -0.04 \\
& $(-1.5)$ & $(-1.8)$ \\
Long-run effect of $I$ on $L$ & -0.01 & -0.01 \\
$R^{2}$ adjusted & $(-2.8)$ & $(-2.3)$ \\
\end{tabular}

Notes: $L(-1)$ and $I$ are in terms of ratio to GDP; $t$-values appear in parentheses.

Table 5.11

Determinants of Portfolio Investment Inflows

\begin{tabular}{lcc}
\hline & OLS & TSLS \\
\hline Output growth, DY & -0.0004 & 0.003 \\
& $(-0.025)$ & $(0.12)$ \\
Lagged portfolio investment, $P(-1)$ & 0.37 & 0.37 \\
& $(3.9)$ & $(3.9)$ \\
Domestic investment, $I$ & 0.003 & 0.001 \\
& $(0.2)$ & $(0.05)$ \\
Lagged domestic investment, $I(-1)$ & 0.01 & 0.01 \\
& $(0.3)$ & $(0.4)$ \\
Dummy for multiple exchange rates, Res1 & -0.002 & -0.002 \\
(one exchange rate = 0; more than one $=1)$ & $(-0.72)$ & $(-0.6)$ \\
Long-run effect of $I$ on Port & 0 & 0 \\
$R^{2}$ adjusted & 0.15 & 0.15 \\
\hline
\end{tabular}

Notes: $P(-1)$ and $I$ are in terms of ratio to GDP; $t$-values appear in parentheses. 
regression analysis effectively flashes out an autocorrelation process of the portfolio investment flows.

\section{Summary}

We now summarize the main findings of the panel data analysis concerning interactions between capital inflows and investment in capacity (or growth):

1. Foreign direct investment flows have a larger (independent) effect on domestic investment in capacity (or growth) than loan inflows or foreignportfolio inflows.

2. Domestic investment in capacity (or output growth) has more pronounced effects on FDI inflows than on either loan inflows or foreignportfolio inflows.

\subsection{Conclusion}

Kindleberger (1969) suggests that in order to think about FDI we must ask not why capital might flow into a country, but rather why some particular asset would be worth more under foreign than under domestic control. In this chapter I discuss empirical implications of a new theory of FDI, which captures a unique feature: hands-on management standards that enable investors to react in real time to the changing economic environment surrounding the investors. Equipped with superior managerial skills, foreign direct investors are able to outbid portfolio investors for the top productivity firms in a particular industry in which they have specialized in the source country. Consequently, FDI investors would make investment both larger and higher quality than the domestic investors. The theory can explain both two-way FDI flows among developed countries and one-way FDI flows from developed to developing countries. Gains to the host country from FDI stem from the informational value of FDI.

Main predictions of the theory are consistent with evidence from panel data: Larger FDI coefficients in the domestic-investment and outputgrowth regressions relative to the portfolio equity and international loans inflow coefficients reflect a unique role for FDI in the domestic investment and growth process.

Does this mean that the chapter brings out a case for subsidizing either domestic investment in capacity (because it brings in more FDI) or FDI (because it helps domestic investment in capacity and growth)?

A cautionary word based on the Irish case is in order. One can argue, convincingly, that the heavy subsidization of FDI inflows in Ireland in the past two decades resulted in impressive GDP growth rates but with less pronounced effect on the well-being of Irish residents, as crudely measured by the Irish gross national product growth rates. Thus, gains to the host 
country are not fully captured by the increase in domestic investment in capacity, to which FDI inflows give rise.

\section{Appendix A}

\section{List of Sixty-Four Countries in HRS Estimation}

$\begin{array}{llll}\text { Algeria } & \text { Costa Rica } & \text { Korea, Republic of } & \text { Rwanda } \\ \text { Argentina } & \text { Cote d'Ivoire } & \text { Lesotho } & \text { Senegal } \\ \text { Bangladesh } & \text { Dominica } & \text { Malawi } & \text { Sierra Leone } \\ \text { Belize } & \text { Ecuador } & \text { Malaysia } & \text { South Africa } \\ \text { Benin } & \text { Egypt, Arab Republic of } & \text { Mali } & \text { Sri Lanka } \\ \text { Bolivia } & \text { Gabon } & \text { Mauritania } & \text { St. Vincent and the } \\ \text { Botswana } & \text { The Gambia } & \text { Mauritius } & \text { Grenadines } \\ \text { Brazil } & \text { Ghana } & \text { Mexico } & \text { Swaziland } \\ \text { Burkina Faso } & \text { Grenada } & \text { Morocco } & \text { Syrian Arab Republic } \\ \text { Burundi } & \text { Guatemala } & \text { Nepal } & \text { Thailand } \\ \text { Cameroon } & \text { Guyana } & \text { Niger } & \text { Togo } \\ \text { Central African } & \text { India } & \text { Nigeria } & \text { Trinidad and Tobago } \\ \text { Republic } & \text { Indonesia } & \text { Pakistan } & \text { Tunisia } \\ \text { Chad } & \text { Israel } & \text { Papua New Guinea } & \text { Uruguay } \\ \text { Chile } & \text { Jamaica } & \text { Peru } & \text { Zambia } \\ \text { Colombia } & \text { Jordan } & \text { The Philippines } & \text { Zimbabwe } \\ \text { Congo, Republic of the } & \text { Kenya } & & \end{array}$

\section{Sources of Data}

The principal source of data is the World Bank WDI 2000 CD-ROM. Capital control data were taken from IMF publications.

A few missing data items regarding loans for Israel were taken from the Bank of Israel resources.

\section{Appendix B \\ Definitions of Series}

Terms of trade: (DTT) adjustment (constant LCU) (NY.TTF.GNFS.KN). The terms-of-trade effect equals capacity to import less exports of goods and services in constant prices. Data are in constant local currency. The change is calculated as the difference from one year to the other.

Public spending on education: (ED3), total (\% of GNP, UNESCO) (SE.XPD.TOTL.GN.ZS). Public expenditure on education (total) is the percentage of GNP accounted for by public spending on public education plus subsidies to private education at the primary, secondary, and tertiary levels. For more information, see WDI table 2.9. 
GDP per capita: (CY), PPP (current international \$) (NY.GDP.PCAP. PP.CD). GDP per capita based on purchasing power parity (PPP). GDP PPP is gross domestic product converted to international dollars using PPP rates. An international dollar has the same purchasing power over GDP as the U.S. dollar in the United States. Data are in current international dollars. For more information, see WDI tables 1.1, 4.11, and 4.12. For the estimation we used the logarithm of CY.

Foreign direct investment: (FDI), net inflows ( $\%$ of GDP) (BX.KLT. DINV.DT.GD.ZS). Foreign direct investment is net inflows of investment to acquire a lasting management interest (10 percent or more of voting stock) in an enterprise operating in an economy other than that of the investor. It is the sum of equity capital, reinvestment of earnings, other longterm capital, and short-term capital as shown in the balance of payments. For more information, see WDI table 5.1.

General government consumption: ( $G$ ) (\% of GDP) (NE.CON.GOVT. ZS). General government consumption includes all current spending for purchases of goods and services (including wages and salaries). It also includes most expenditures on national defense and security but excludes government military expenditures that are part of government capital formation. For more information, see WDI table 4.9.

Gross domestic investment: (I) (\% of GDP) (NE.GDI.TOTL.ZS). Gross domestic investment consists of outlays on additions to the fixed assets of the economy plus net changes in the level of inventories. Fixed assets include land improvements (fences, ditches, drains, and so on); plant, machinery, and equipment purchases; and the construction of roads, railways, and the like, including commercial and industrial buildings, offices, schools, hospitals, and private residential dwellings. Inventories are stocks of goods held by firms to meet temporary or unexpected fluctuations in production or sales. For more information, see WDI tables 1.4 and 4.9.

GDP growth: (DY) (annual \%) (NY.GDP.MKTP.KD.ZG). Annual percentage growth rate of GDP at market prices based on constant local currency. Aggregates are based on constant 1995 U.S. dollars. For more information, see WDI tables 4.1 and 4.2.

Portfolio investment: $(P)$, excluding LCFAR (BoP, current US\$) (BN. KLT.PTXL.CD). Portfolio investment excluding liabilities constituting foreign authorities' reserves covers transactions in equity securities and debt securities. Data are in current U.S. dollars. This series was divided in the matching GDP to get the portfolio investment as a share of GDP.

Bank and trade-trade lending: ( $L$ ) (PPG + PNG) (NFL, current US\$) (DT.NFL.PCBO.CD). Bank and trade-related lending covers commercial bank lending and other private credits. Data are in current U.S. dollars. For more information, see WDI table 6.7. This series was divided in the matching GDP to get the loans flows as a share of GDP.

Total financial flows: (TLY64F) is the sum of FDI, total portfolio flows 
(PLY64), and total loans (OLY64), where flows are divided by GDP. Data include sixty-four developing countries.

Capital controls: Data on capital controls for all IMF member countries, years 1966-97. Dummy takes the value 1 when a restriction is in place, and 0 otherwise.

1. Multiple exchange rates (Res1)

2. Restrictions on current account transactions (Res2)

3. Restrictions on capital account transactions (Res3)

4. Surrender of export proceeds (Res4)

\section{References}

Albuquerque, Rui. 2003. The composition of capital flows: Risk sharing through foreign direct investment. Journal of International Economics 61:353-83.

Blomström, Magnus, Ari Kokko, and Steven Globerman. 2001. The determinants of host country spillovers from foreign direct investment: A review and synthesis of the literature. In Inward investment, technological change and growth: The impact of multinational corporations on the U.K. economy, ed. N. Pain, 34-65. New York: Palgrave Press.

Borensztein, Eduardo, Jose De Gregorio, and Jong-Wha Lee. 1998. How does foreign direct investment affect growth? Journal of International Economics 45:115-35.

Bosworth, Barry P., and Susan M. Collins. 1999. Capital flows to developing economies: Implications for saving and investment. Brookings Papers on Economic Activity, Issue no. 1:143-69.

Caves, Richard E. 1971. International corporations: The industrial economics of foreign investment. Economica 38:1-27.

Froot, Kenneth A. 1991. Japanese foreign direct investment. In US-Japan economic forum, ed. Martin Feldstein and Yoshi Kosai. Cambridge, Mass.: National Bureau of Economic Research and Japan Center for Economic Growth.

Hart, Oliver. 2000. Financial contracting. Journal of Economic Literature 39 (4): 1079-110.

Hecht, Joel, Assaf Razin, and Nitsan Shinar. 2003. Interactions between capital flows and investment. Foreign Exchange Activity Department working paper. Jerusalem: Bank of Israel, February.

Helpman, Elhanan. 1984. A simple theory of international trade with multinational corporations. Journal of Political Economy 92:451-71.

Kindleberger, Charles P. 1969. American business abroad: Six lectures on direct investment. New Haven, Conn.: Yale University Press.

Loungani, Prakash, and Assaf Razin. 2001. How beneficial is foreign direct investment for developing countries? Finance and Development 38 (2): 6-10.

Mody, Ashoka, Assaf Razin, and Efraim Sadka. 2002. The role of information in driving FDI: Theory and evidence. NBER Working Paper no. 9255. Cambridge, Mass.: National Bureau of Economic Research.

Razin, Assaf, and Efraim Sadka. 2002. Labor, capital, and finance: International flows. New York: Cambridge University Press.

2003. Gains from FDI inflows with incomplete information. Economics Letters 78 (1): 71-77. 
Razin, Assaf, Yona Rubinstein, and Efraim Sadka. 2003. Which countries export FDI, and how much. NBER Working Paper no. 10145. Cambridge, Mass.: National Bureau of Economic Research.

\section{Comment Kyoji Fukao}

Assaf Razin's paper proposes an interesting new theory of foreign direct investment (FDI). The new theory is based on the following two assumptions:

1. Some foreign investors can get information on the optimal investment level of local firms at a lower fixed cost than firms in the host country.

2. A potential buyer needs to acquire the local firm in order to apply its technology.

According to Razin, FDI is the result of informational advantages of foreign firms. In contrast with this, the standard theory regards FDI as international movements of intangible assets, such as the stock of technological knowledge or marketing know-how. ${ }^{1}$ Foreign firms conduct direct investment because they can carry out production at a lower cost or have better marketing skills. Since international mergers and acquisitions (M\&As) have increased substantially in the last decade and asymmetric information issues seem to play an important role in M\&A processes, Razin's new theory is very timely and provides a useful contribution to the study on international M\&As.

I have three comments. My first comment is on the applicability of the new theory to "green field" investments. Although cross-border M\&As have rapidly increased especially in the case of FDI among developed economies, the majority of direct investments into developing economies are still of the "green field" type. Table 5C.1 shows the share of M\&A-type investments in total FDI flows in each region during the period from 1997 to 1999. According to this table, in the case of FDI inflows into developing Asia, only 21 percent of total FDI consisted of M\&As. In Razin's paper the new theory is applied to the empirical study based on data of total FDI flows. I think that the author had better elaborate on the applicability of his new theory to green field investments.

My second comment concerns the identification problem. In the empirical part of the paper, the author provides several interesting pieces of evi-

Kyoji Fukao is professor of economics at the Institute of Economic Research, Hitotsubashi University, and a fellow at the Research Institute of Economy, Trade and Industry.

1. On the standard theory of FDI, see Caves (1982) and Dunning (1977). 


\begin{tabular}{ll}
\hline & $\%$ \\
\hline United States & 78 \\
Western Europe & 79 \\
Latin America & 59 \\
Central and Eastern Europe & 34 \\
Developing Asia & 21 \\
Developing countries total & 30 \\
\hline
\end{tabular}

Source: UNCTAD, World Investment Report 2000, 2000.

dence that are consistent with the prediction of the theory: Compared with portfolio investment, inward FDI has a larger positive effect on domestic investment and economic growth in the host country. Although such findings are interesting, the "evidence" provided does not prove the validity of the new theory since we can also explain these phenomena using the standard theory. According to the standard theory, FDI will increase the stock of intangible assets, such as technological knowledge or marketing knowhow in the host country, which will enhance domestic investment and economic growth. I hope that in future the author provides us with some new implications and tests by which we can empirically distinguish the new theory from the standard theory.

My last comment is on the relationship between a parent company and its affiliates abroad. In East Asian manufacturing industry, there exist close linkages and coordination between parents and their affiliates. Production processes are commonly fragmented within an enterprise group, and unskilled labor-intensive processes are located in developing countries such as China. ${ }^{2}$ Multinationals engage in FDI in developing East Asia not to make profits from their superior knowledge on investment timing but to establish efficient global production networks by combining their advanced technologies with developing countries' cheap labor.

To sum up my comments, Razin's paper gives us important new insights on FDI, especially on M\&As, but it seems that we cannot directly apply his theory to efficiency-seeking green field-type FDI in manufacturing industries, which is the dominant form of FDI in East Asia.

\section{References}

Caves, Richard E. 1982. Multinational enterprise and economic analysis. Cambridge, U.K.: Cambridge University Press.

Dunning, John H. 1977. Trade, location of economic activity, and the multinational enterprise: A search for an eclectic approach. In The international allo-

2. On Japanese firms' intra-firm-group fragmentation of production processes, see Kimura (2001). 
cation of economic activity, ed. B. Ohlin, P. O. Hesselborn, and P. M. Wijkman, 395-418. London: Macmillan.

Kimura, Fukunari. 2001. Fragmentation, internalization, and inter-firm linkages: Evidence from the micro data of Japanese manufacturing firms. In Global production and trade in East Asia, ed. Leonard K. Cheng and Henryk Kiezkowski, 129-52. Boston: Kluwer Academic.

\section{Comment Dean Parham}

Assaf Razin's paper is now rather different from the one he presented at EASE-13. I have adapted my comments by generalizing my original remarks and adding a few more that are specifically directed at the paper as it now stands. My remarks have been informed in part by material provided in a recent study of foreign direct investment by the Productivity Commission (2002).

Foreign direct investment (FDI) is an important issue. It has been growing faster than world GDP, especially since the late 1990s (fig. 5C.1). The author's work investigates "commercial" motivations for FDI, which are becoming more important in a world of fewer barriers to investment flows and growing maturity of financial markets and institutions. The relative importance of commercial motives was illustrated in a recent survey of Australian firms engaging in outward FDI (figs. 5C.2 and 5C.3).

The paper also distinguishes between FDI, portfolio investment, and loans. It recognizes that free-rider problems induce different behavior on the part of FDI and portfolio investors. Foreign direct investment is seen to promote growth through a higher amount and more efficient allocation of investment. Some prima facie support for this proposition lies in the improvement (or lessened deterioration) in capital productivity growth in Australia that has coincided with increased inward FDI in the 1980s and 1990s (fig. 5C.4).

The examination of FDI, portfolio, and loan flows and their effects on domestic investment flows - all in a simultaneous framework - is the main novel feature of the paper. I will make a few comments about the theoretical motivation in the paper before looking at the empirical results.

\section{Theoretical Motivation}

Necessary preconditions for FDI are commonly thought to include the following factors:

- The foreign firm has some firm-specific assets (e.g., proprietary technology, know-how) that it wishes to use to advantage.

Dean Parham is assistant commissioner at the Productivity Commission, Australia. 


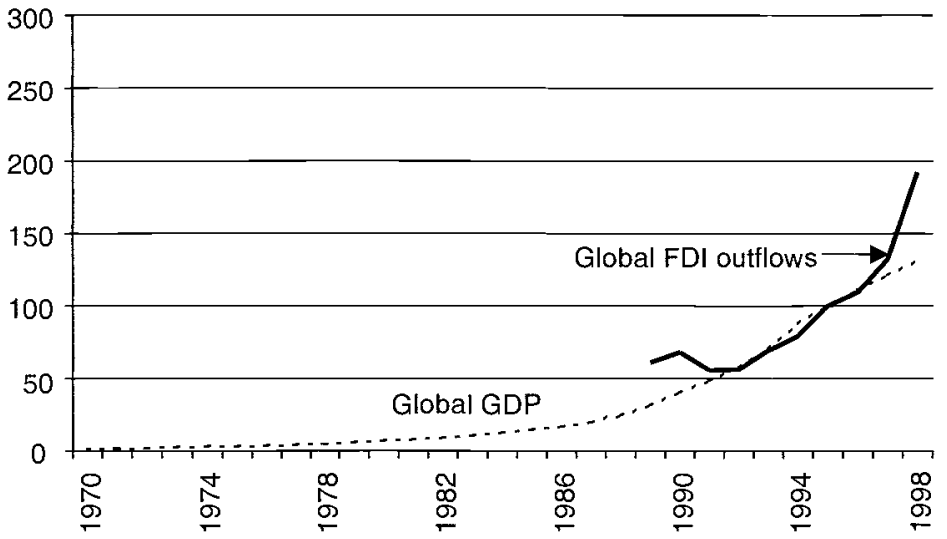

Fig. 5C.1 Global trends in outward FDI flows and GDP (index $1995=100$ ) Source: Productivity Commission (2002).

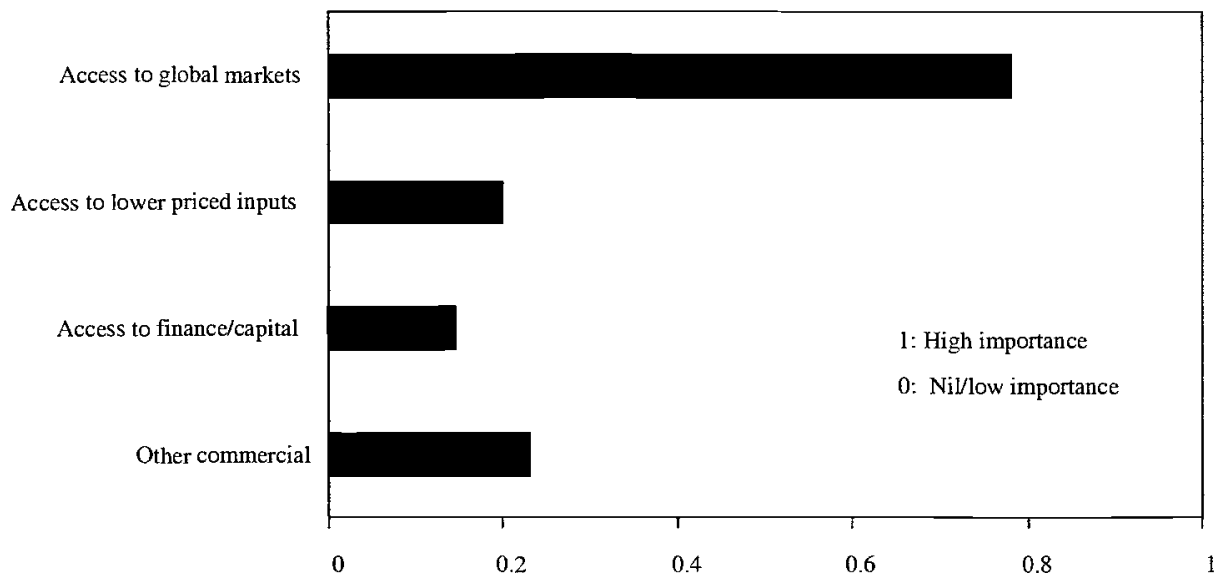

Fig. 5C.2 Commercial motives for offshore production

Source: Productivity Commission (2002).

- There are net locational advantages for the foreign firm in the host country (e.g., access to large markets, lower costs). ${ }^{1}$

- There are advantages in internalizing operations (through a branch operation) rather than relying on markets to exchange goods and services between foreign and local firms. For example, there may be difficulties in specifying requirements between foreign and local firms by means of contracts - a problem that may be intensified with the growth in "knowledge-intensive" production processes.

1. Advantages, such as lower transportation costs, need to outweigh disadvantages of perhaps less local knowledge, and so on. 


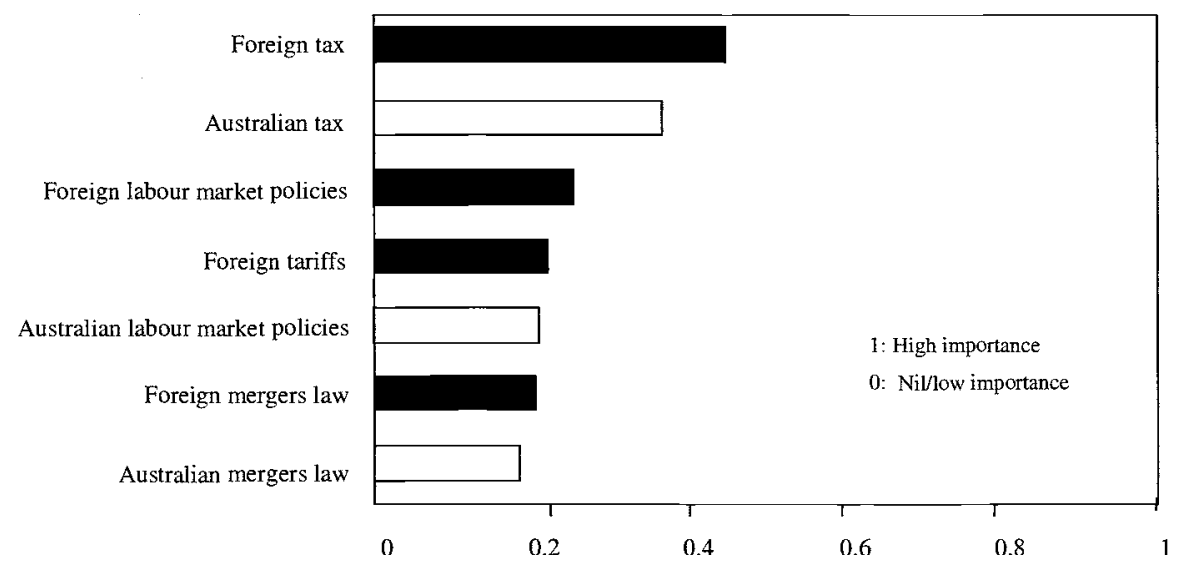

Fig. 5C.3 Government influences on offshore production Source: Productivity Commission (2002).

The paper identifies an advantage to the foreign firm in the form of superior micromanagement. This most clearly fits with the first of the aforementioned motivations. But it has more to do with management skill than proprietary technology. It confers an advantage on FDI that is not available to portfolio investment.

The theoretical specification appears to invoke some simplifications. The foreign-firm advantage, in the form of better micromanagement, can be available to all foreign firms. Foreign firms are able to compete away the gains from their advantage. But the advantage is available to no domestic firm. This seems to require a production factor that can jump everywhere, except over country borders (or, more specifically, the border to the one country considered as a target).

Domestic firms appear to be homogeneous with respect to productivity performance (and inferior management). In practice, foreign firms are likely to decide on

- whether to establish a local branch presence (with brand name) or take over a local firm; and,

- if they decide on a takeover, whether to take over high-performing or underperforming firms, depending on expectations of productivity (or profit) growth across the range of firms.

The foreign-firm advantage can be competed away and captured by the domestic economy in the form of higher takeover prices. The advantage of foreigners is reflected in bid prices. If the advantage is not firm specific, foreign firms would have to build expectations about other foreign firms' bids into their own bids. This is where the competition appears to take placein the bids. With perfect competition between foreign FDI bidders, the 


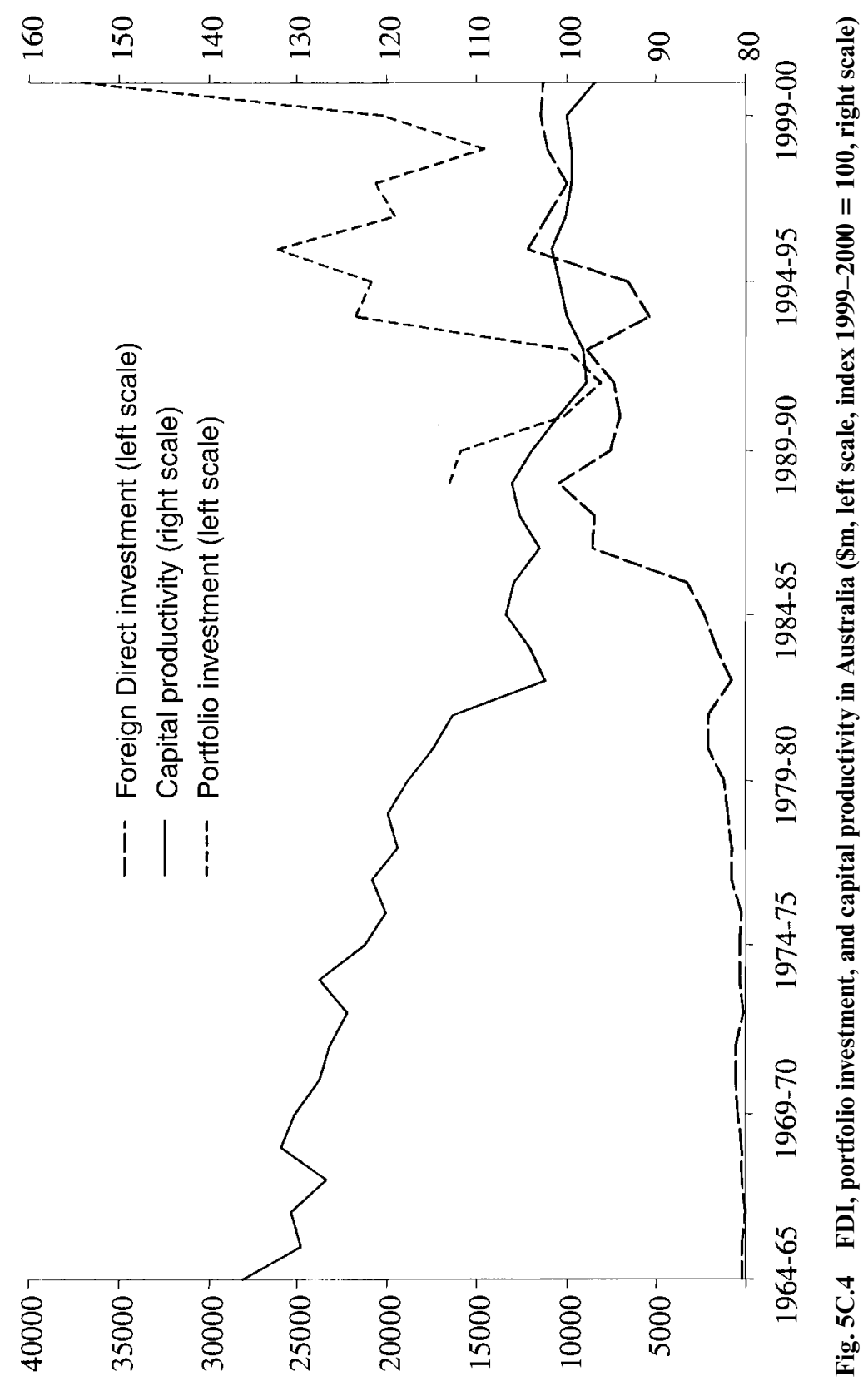


gains from the management advantage are fully transferred to the domestic economy.

A richer model might involve foreign firms with firm-specific advantages, such as proprietary technology, seeking out a suitable target from local firms with a range of productivity or profit performances, and choosing one that is expected to deliver the strongest productivity or profit growth. If the extent of the "advantage" is specific to the combination of domestic firm and foreign firm, the takeover could include an underperforming domestic firm. The foreign firm would also get a semipermanent advantage that could not be competed away by other foreign or domestic firms and not necessarily "the cream." They would still "add cream" to the local economy because they bring technology and raise performance.

Finally, the model seems to predict a level effect on investment, efficiency, and GDP as foreign firms exploit the extent of their advantage. Canadian evidence, at least, tends to suggest that inward FDI has important growth effects (Baldwin and Dhaliwal 2001).

\section{Empirical Results}

One general comment - and this is probably common to a lot of work in this area-is that there does not seem to be a tight nexus between the theory and the empirics. Perhaps I missed something, but it is not immediately obvious to me how the empirical model necessarily provides a test of the micromanagement advantage of foreign firms. I wonder whether other advantages (such as proprietary technology) and motivations could be consistent with the empirical model used.

As noted, the capital flows are analyzed in a simultaneous framework. A key finding is the confirmation that these flows have positive effects on domestic investment. Long-run effects from two-stage least squares estimation put the FDI effect $(0.68)$ at double the loan effect $(0.35)$ with the portfolio effect (0.53) in between. Compared with the Bosworth and Collins (1999) results, the FDI effect is a little weaker, the portfolio effect is much stronger (there is no discernible effect in Bosworth and Collins), and the loan effect is a little stronger. Some further exploration of the reasons for these differences-be they in the simultaneous specification (Bosworth and Collins found the different types of flows to be unrelated) or equation specification or other reasons - might help interpretation.

It is also interesting to note that the different types of capital flows are all found to have positive effects on growth. As might be expected, FDI is found to have a stronger effect.

\section{References}

Baldwin, John R., and Naginder Dhaliwal. 2001. Heterogeneity in labour productivity growth in manufacturing: Differences between domestic and foreign- 
controlled establishments. In Productivity growth in Canada, 61-75. Ottawa: Statistics Canada.

Bosworth, Barry P., and Susan M. Collins. 1999. Capital flows to developing economies: Implications for saving and investment. Brookings Papers on Economic Activity, Issue no. 1:143-69.

Productivity Commission. 2002. Offshore investment by Australian firms: Survey evidence. Commission Research Paper. Canberra, Australia: AusInfo. 
- II

Micro Productivity 
